\title{
A Study of News Frames on the Controversy over Evolutionary Theories in South Korean Science Textbooks
}

Younghoon Jeong*

\section{A Major Evolution Controversy in Korea}

In December 2011 and March 2012, South Korea's Ministry of Education, Science and Technology (currently the Ministry of Education) received a "revision petition" from an organization named "Society for Textbook Revision (STR) ${ }^{1}$." STR belonged to a Christian foundation called the Korea Association for Creation Research. The two petitions, specifically addressed to the Minister of Education, Science and Technology, were respectively titled "Archaeopteryx is Not a Transitional Species between Reptiles and Birds," and "The Evolutionary Lineage of the Horse is a Pure Imagination." STR demanded that the contents pertaining to these subjects should be deleted from high school textbooks.

The Korean government forwarded the petitions to seven science textbook publishers, asking them to use their discretion on the issue. In the end, most of the publishers responded that they would remove the related

\footnotetext{
* Contents Biz Team Director, Seoul Cultural Publishers Inc., Seoul, South Korea

1 www.str.or.kr The Society for Textbook Revision (STR) was founded on Oct. 31, 2009 by organizations and individuals who had been researching errors regarding the evolutionary theory. STR is an academic society that includes a science committee and an advisory committee. It also runs the Textbook Revision Research Institute.
} 
contents. Although many scientists who heard this news expressed concerns, the issue was not covered by the media at that time. However, the case received international attention after a freelance writer Soo Bin Park contributed an article, "South Korea Surrenders to Creationist Demands," to the respected British science journal Nature, which in turn was covered by the American weekly news magazine Time. Only then did the Korean media belatedly begin to report on the issue, while an embarrassed government scurried to cope with the controversy.

The Ministry of Education, Science and Technology (MEST) announced that two leading scientific organizations, the Korean Federation of Science and Technology Societies and the Korean Academy of Science and Technology were assigned with the mission to lead discussions on the issue and submit "the predominant opinion of the scientific communities" in order to make a final decision. Thus, the 2012 controversy over the evolution of Archaeopteryx and horses in textbooks turned out to be a sensitive and significant issue not only in the scientific world but in Korea as a whole, as it gave rise to the first public debates on evolutionism in the country.

How, then, did the controversy get across to the public? Was it reported in a timely manner? In what frame did the media report on the subject? This study is intended to investigate the attitudes of the media coverage on a major evolution controversy in South Korea: Whether the issue was reported in a timely and proper manner and if there were any notable aspects in the media coverage. The ultimate purpose of this research is to determine the Korean media's problems with reporting on sensitive scientific issues and their solutions.

\section{Theories, Objects, and Methods}

It is commonly believed that the media objectively reports the facts. But many previous studies have shown that the news media actually (re)construct reality, thereby leading the public's perceptions and con- 
sciousness in certain directions. In other words, the media cast a certain frame on the readers' understanding and interpretation by selecting, emphasizing, and summing up realities before showing them to the public. As a result, the public accepts "framed" realities. Therefore, the media's framing is a crucial factor that affects the public's perceptions and even their opinions about social issues that are closely related to their lives. The frame herein is defined as "a mold that structures reality." The frame structures discussions about reality systematically and gives meaning to them by either emphasizing certain information or excluding it. $^{2}$

The media can cast a mold of thinking on an issue by a framing technique that highlights or deletes certain aspects of the issue leading the public to understand the issue in certain ways. ${ }^{3}$ The word "frame" is known to have been first suggested by Erving Goffman to mean "the framework of a story." Framing has become a common tool to analyze news reports. As Goffman defined "frame" as a framework of a story, he proposed one of the major epistemological paradigms of journalism, namely, "the constructive viewpoint," which posited that the reality is constructed on a sociocultural level and then interpreted and perceived at the individual's level in certain manners, instead of being conveyed wholly and transparently by the media.

This study examines the news frames in terms of formal frame and content frame. As for formal frame, I focus on the episodic frame and the thematic frame that Iyengar suggested to measure the influences of media frames on consumers. ${ }^{4}$ There are the four types of content frames highlighted by Semetko and Valkenburg, including "conflict," "responsibil-

2 Todd Gitlin, The Whole World is Watching: Mass Media in the Making and Unmaking of the New Left (Berkeley: University of California Press, 1980).

3 Robert M. Entmann, "Framing U. S. Coverage or International News: Contrast in Narratives of the KAL and Iran Air Incident," Journal of Communication 41, issue 4 (December 1991).

4 Shanto Iyengar, Is Anyone Responsible?: How Television Frame Political Issues (Chicago: University of Chicago Press, 1991). 
ity," "human interest," and "economic consequence frames." I investigate the first three frames used by major Korean newspapers regarding the evolution controversy. In this study, the frame of "economic consequence" has been excluded since it is irrelevant to this case. Instead, I use the frame of "scientific interpretation," as I deal with news on science and technology. Another frame added is that of "errors of evolutionary theories" which addresses "unscientific elements and mistakes" in the theories of evolution as a key feature in some newspaper articles.

The objects of my analysis are eight broadsheet Korean newspapers. They are divided into those owned by religious foundations - Kukmin Ilbo and Segye Ilbo; the leading conservative papers - Chosun Ilbo, JoongAng Ilbo and Dong-A Ilbo; the leading progressive papers - Hankyoreh and Kyunghyang Shinmun; and Seoul Shinmun. ${ }^{6}$ I have also introduced a periodization according to the major turning points of the controversy: these are the starting period - December 1, 2011 to June 6, 2012; the conflict period - June 7, 2012 to September 6, 2012; the resolution period - September 7, 2012 to April 30, 2013.

My research method is to review all of the articles that are found on the homepages of KINDS (www.bigkinds.or.kr) and media outlets and in the news library of the NAVER search engine. A major point of analysis is the amount of media coverage, which is based on the number of articles. From the database, I have counted the number of articles rather than the position or length of the articles in the newspapers. As to the type of reporting, I have classified articles into straight reporting and opinion reporting. Informants are also a decisive factor for news coverage. I have classified the informants of articles into (1) individuals or organizations

5 Holli A. Semetko and Patti M. Valkenburg, "Framing European Politics: A Contest Analysis of Press and Television News," Journal of Communication 50, issue 2 (June 2000).

6 Seoul Shinmun was presumed worthy of studying as it reported the evolution controversy from the beginning to the resolution period, recording the most coverage amount on a steady basis. 
in science; (2) individuals or organizations in religion; (3) foreign media; (4) government officials or organizations; (5) individuals or companies in the publishing business; (6) investigation authorities: prosecution and police; (7) netizens; (8) others, or no informants. Each article's attitude toward evolution has been classified into (1) being critical; (2) supportive; (3) neutral or not biased. The formal frames that I use in my research are classified into (1) episodic; (2) thematic. The content frames are divided into (1) conflict; (2) responsibility; (3) human interest; (4) scientific interpretation; and (5) errors of evolutionary theories.

In this study, I have also conducted in-depth interviews with five journalists who reported on the evolution controversy. For the interview I have chosen newspapers that represented different political inclinations: Dong-A Ilbo (Donga Science) among the conservative, Kyunghyang Shinmun among the progressive. Other newspapers Kukmin Ilbo, Segye Ilbo and Seoul Shinmun were also included to cover diverse viewpoints. The in-depth interviews of the five journalists were intended to address the questions below:

1. Why did you, or did you not, pay attention to the evolution controversy of Korea?

2. What structural limits do you find in the domestic science journalism regarding this issue?

3. How much influence do the NSC journals (Nature, Science, and Cell) have on Korean science journalism?

4. Do you face pressures from the company or the desk in reporting? If so, how significant are they?

5. Was the ideological frame of the paper's conservative or progressive inclination applied to this issue?

6. Why did the two papers owned by a religious foundation show different attitudes toward this issue?

7. Why did the controversy die down so fast given the significance of the issue? Is it possible for the controversy to resurface? 


\section{Results of Newspaper Analysis}

The analysis of the coverage of the eight newspapers showed that Seoul Shinmun carried the most articles, numbering 18 in total. Kukmin Ilbo ranked the second with 16 articles, while JoongAng Ilbo was at the bottom with only four articles. Overall coverage by the eight newspapers amounted to 84 articles. <Table $1>$ illustrates the changing number of articles on the issue in eight newspapers. It shows that most of the newspapers except Kukmin Ilbo did not report on the issue in the beginning period when STR submitted the revision petition. Kukmin Ilbo, which is owned by a religious foundation, followed up on STR's activities from the beginning whereas the rest of the papers paid little attention to the issue at that time, as shown in $<$ Table $1>$.

This graph shows a sudden surge of coverage around the time the journal Nature posted Soo Bin Park's article. After the renowned international journals and magazines including Nature, Science, and Time published the story, the Korean media outlets rushed to cover the case. In particular, the domestic science journalism was presumably influenced to a certain degree by the reporting of NSC (Nature, Science and Cell). It is also noteworthy that the media coverage concentrated on the conflict phase of the issue as the coverage in this period accounted for $59.5 \%$ of the overall reporting, compared with the beginning period of $9.5 \%$ (eight articles) and the resolution period of $29.8 \%$ ( 25 articles).

The analysis of reporting type indicated that 54 out of the total 84 articles, or $64.3 \%$, were straight reporting consisting of facts without the journalists' opinion or interpretation. The remaining 30 pieces, or $35.7 \%$, were opinion articles where the writers added their interpretation and opinion to the news.

The analysis of informants ranked "individuals/organizations in science" at the top, accounting for $29.0 \%$ and "netizens" the lowest at $2.7 \%$ (Figure 2). It was quite plausible that the biggest portion of the informants on such a sensitive technical issue were individuals and organizations related to the field. The second largest group was "individuals/organizations 


\begin{tabular}{|c|c|c|c|c|c|c|c|c|c|c|c|c|}
\hline \multicolumn{2}{|c|}{ 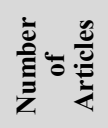 } & & $\infty \stackrel{\sqrt[n]{a}}{a}$ & 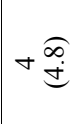 & $\infty \stackrel{\tilde{n}}{a}$ & 을 & $\sigma \stackrel{\hat{\theta}}{\theta}$ & 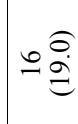 & $\infty \stackrel{\tilde{n}}{\sigma}$ & $\stackrel{\infty}{\stackrel{\Im}{d}}$ & × & \\
\hline \multirow{4}{*}{ 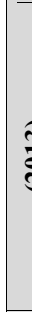 } & 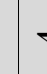 & & & & & 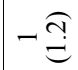 & & & & & $-\stackrel{\widehat{A}}{g}$ & \multirow{8}{*}{ 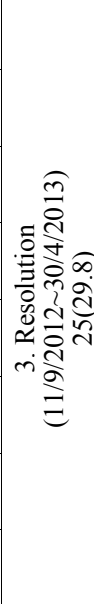 } \\
\hline & & & & & & & & & & & 0 & \\
\hline & . & & & & & & & & & $-\widehat{\overparen{C}}$ & $-\stackrel{\overparen{C}}{\Theta}$ & \\
\hline & - & & & & & $-\stackrel{\overbrace{}}{\overparen{C}}$ & $\sim \stackrel{f}{\mathcal{d}}$ & $-\stackrel{\overparen{\mathcal{C}}}{\Theta}$ & & & $+\underset{+}{\stackrel{\infty}{+}}$ & \\
\hline \multirow{12}{*}{ ิㅗㄹ } & $=$ & & & & & & & 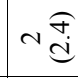 & & $-\stackrel{\overparen{\overbrace{}}}{\Xi}$ & 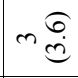 & \\
\hline & $=$ & & & & & & & & & N & ح & \\
\hline & 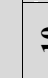 & & $-\stackrel{\widehat{\overparen{C}}}{\mathscr{\Xi}}$ & $-\stackrel{\overparen{T}}{\circledast}$ & & & $-\stackrel{\overbrace{}}{\overbrace{}}$ & & $\sim \stackrel{\overbrace{}}{d}$ & $\sim \stackrel{\mathcal{f}}{d}$ & - $\underset{\infty}{\infty}$ & \\
\hline & 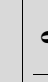 & & 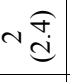 & & N & 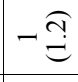 & 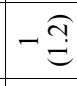 & & & 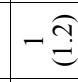 & - $\underset{\infty}{\infty}$ & \\
\hline & $\circ$ & & & & & & & & & $-\stackrel{\overbrace{}}{\overparen{\overbrace{}}}$ & 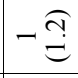 & $\pm \widetilde{I}$ \\
\hline & 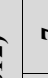 & & ح & $-\stackrel{\overbrace{}}{\overparen{C}}$ & 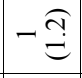 & 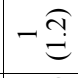 & $-\stackrel{\widehat{\overbrace{}}}{\Xi}$ & m & 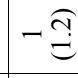 & $\sim \underset{d}{\stackrel{f}{d}}$ & $\simeq \stackrel{\widehat{\tilde{m}}}{\oplus}$ & ํํㅇㅇำ \\
\hline & & & $m \stackrel{\sigma}{\sigma}$ & $\sim \stackrel{\text { }}{\mathrm{d}}$ & n $\underset{\hat{\theta}}{\hat{\theta}}$ & $\sigma \stackrel{\overparen{E}}{\mathscr{E}}$ & 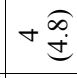 & m & n & గ & $\begin{array}{l}\infty \\
\text { is } \\
\text { r. }\end{array}$ & \\
\hline & 4 & & & & & & & $-\stackrel{\overparen{C}}{\Theta}$ & & $-\stackrel{\widehat{A}}{\Theta}$ & $\sim \stackrel{\mathcal{d}}{\mathrm{d}}$ & \multirow{6}{*}{ 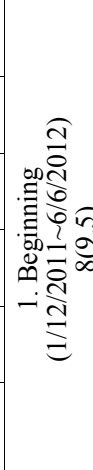 } \\
\hline & 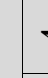 & & & & & & & $\sim \stackrel{\mathcal{d}}{\mathrm{d}}$ & & & N & \\
\hline & . & & & & & & & & & & 0 & \\
\hline & ? & & & & & & & & & & 0 & \\
\hline & 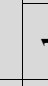 & & & & & & & $\sim \stackrel{f}{\stackrel{d}{d}}$ & & & N & \\
\hline & & 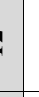 & & & & & & $\sim \stackrel{\overbrace{}}{\stackrel{d}{d}}$ & & & 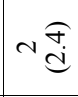 & \\
\hline & 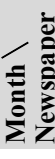 & & 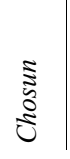 & 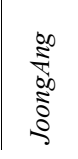 & 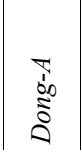 & 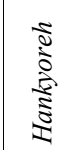 & 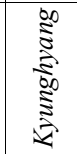 & 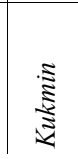 & 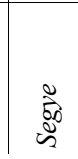 & ڤँ & 急 & \\
\hline
\end{tabular}


Figure 1. The fluctuations of coverage amount over time.

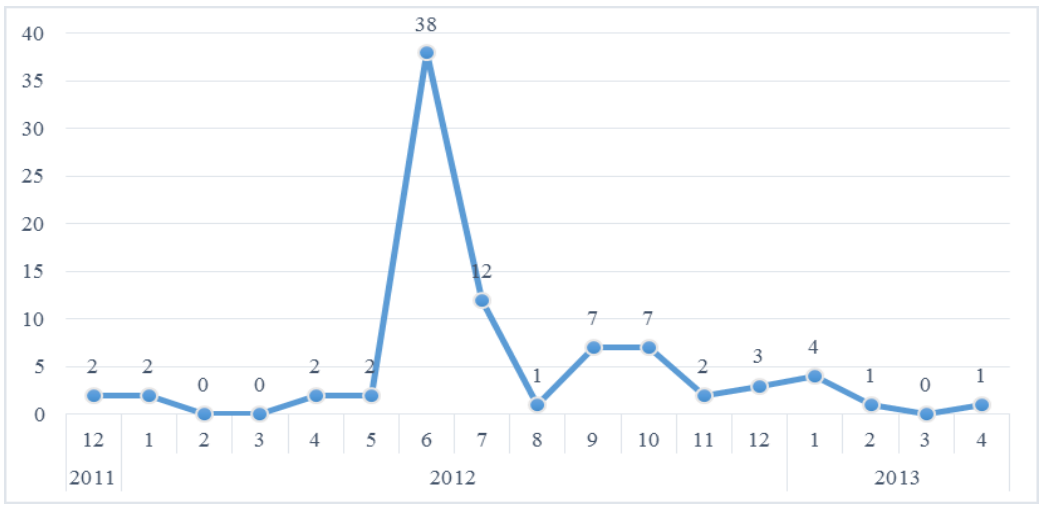

Figure 2. Informants of Articles

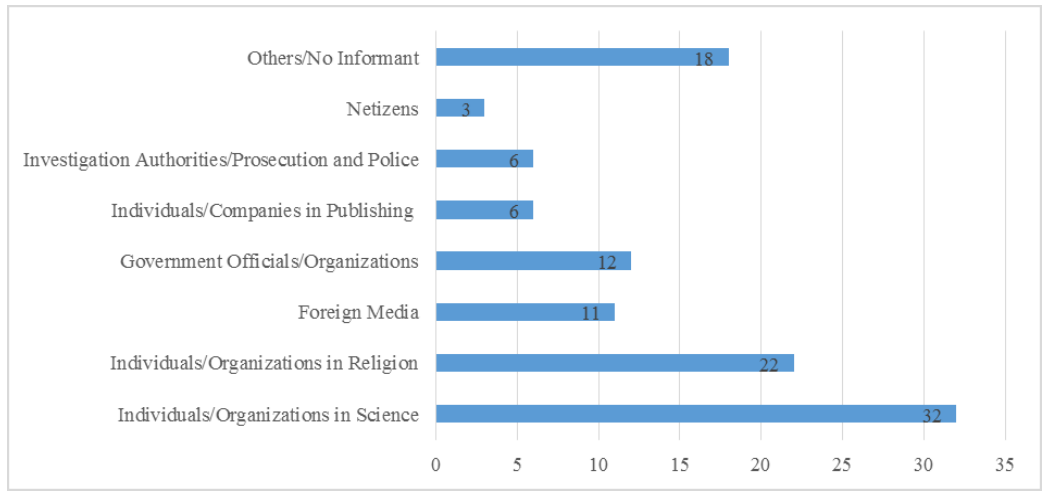

The analysis of the articles' inclination found 54 of them, or $64.3 \%$, to be critical toward STR, $16(19.0 \%)$ to be supportive, and $14(16.7 \%)$ to be neutral or unbiased. The analysis of the articles' formal frames showed the episodic frame accounted for $61.9 \%$ and the thematic frame $38.1 \%$. The analysis of the content frames proved the conflict frame was the most frequent at $30.9 \%$, implying that most of the media outlets approached the controversy as a conflict between science, religion and the government (Figure 3). Especially, as the controversy triggered by STR's petition 
Figure 3. Analysis of Content Frame

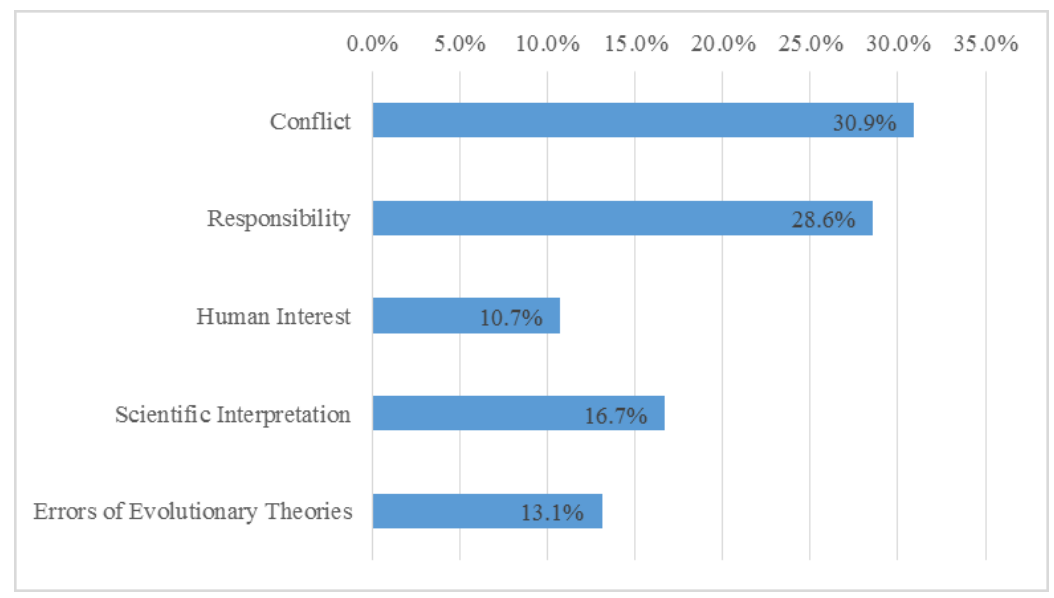

spread into an evolution-creation dispute, the media paid attention to the impact of the debates on Korean society. Seoul Shinmun used the conflict frame most frequently, producing eight articles, followed by Chosun Ilbo with six and Kukmin Ilbo with five articles.

Though the analyses hereinbefore led to quite a few meaningful conclusions, some questions still remain to be answered. Why did the Kukmin Ilbo and Segye Ilbo, the two newspapers owned by a religious foundation, show sharp differences in timing of reporting, coverage amount and the inclination of reports? Why did the leading conservative papers, Chosun Ilbo, JoongAng Ilbo and Dong-A Ilbo not pay attention to the issue, despite its significance? Why did these conservative reports show the same attitude toward the issue as those of the progressives like Hankyoreh and Kyunghyang Shinmun? Why did the Seoul Shinmun alone act swiftly to follow up on the issue, producing a relatively large amount of reports? The Seoul Shinmun's efforts raised awareness of the issue. To answer these questions, I carried out in-depth interviews with five journalists from five newspaper companies who were at work when this issue arose. 
Table 2. Information on Journalists Who Participated in In-depth Interviews

\begin{tabular}{c|c|c}
\hline Name (anonymous) & Media & Years of Work Experience \\
\hline Journalist A & Newspaper & 14 years \\
Journalist B & Newspaper & 6 years \\
Journalist C & Newspaper & 5 years \\
Journalist D & Newspaper & 15 years \\
Journalist E & Newspaper & 12 years \\
\hline
\end{tabular}

The participants of the interview were responsible for science coverage by their newspapers. The list of the five participants is as follows:

\section{Interpretation of the Results}

This study is aimed at assessing the media coverage of the evolution dispute in Korea, which was triggered by a controversy over deleting the evolutionary theory from science textbooks. By clarifying the articles' viewpoints and relevance to the issue and other characteristics, I intend to highlight the problems of the Korean media's attitudes toward sensitive scientific issues and the limitations of domestic scientific journalism and possible solutions.

As explained before, the analysis of the media coverage showed that in the beginning period (right after STR's petitions) most of the broadsheet papers paid little attention to the issue. Only Kukmin Ilbo, owned by a religious foundation, reported steadily on the case trying to cover STR's position. Then came a sharp increase in the coverage amount after Soo Bin Park's article appeared in Nature on June 7, 2012. After the internationally renowned journals and magazines like Nature, Science, and Time covered the story, the domestic media outlets rushed to report on the issue. Another interesting outcome of the analysis indicated that the number of articles on the debate reached its peak in the conflict period at $59.5 \%$. This means most of the reporting focused on the conflict phase of the case 
rather than the beginning and resolution phases. In particular, in the resolution period most of the newspapers hardly tried to follow up on the story.

Ultimately, the overall news coverage remained relatively small, despite the significance of this dispute in Korea. The eight broadsheet newspapers produced 84 articles in total. The lack of reporting seems attributed to a few reasons: First, the evolution controversy produced few facts besides the incident of the textbook revision petition. Second, the media might have reduced the science section or ruled out this issue from the beginning due to the lack of reader interest in scientific news. Third, the controversy may have come to an early end due to the Ministry of Education, Science and Technology's swift response and the textbook revision guidelines offered by the Korean Academy of Science and Technology and other scientific institutions.

As for the type of report, straight reporting articles accounted for $64.3 \%$, with 54 pieces out of the total of $84-$ and the remaining 30 pieces, comprising $35.7 \%$, were classified as opinion articles. This proportion might be related to the fact that evolutionism is a scientific theory and that the textbook controversy is associated with the sensitive evolutioncreation debate. Journalists may have judged that they had rather focus on the facts, leaving opinions up to experts like evolutionary scientists or STR officials in order to produce persuasive articles. The analysis of news informants showed "individuals/organizations in science" accounted for the biggest portion, at $29 \%$. This is understandable as the news dealt with a technical issue. The second biggest group of informants were "individuals/organizations in religion" including STR, accounting for $20 \%$.

The analysis of the tendencies of the articles showed that both the conservative papers (Chosun, JoongAng and Dong-A) and the progressive ones (Hankyoreh and Kyunghyang) were largely critical toward STR and its arguments. Not a single article of these newspapers supported the idea of deleting evolution from textbooks. In other words, the conservatives and the progressives are on the same page toward the textbook evolution controversy. There were no ideological differences regarding this issue 
because the dispute was not considered related to politics, ideology or ethics but about the origin of human beings, a seemingly apolitical subject.

Another notable outcome of this research was the different angles of the two newspapers owned by a religious foundation. While Kukmin Ilbo was supportive in most of its articles toward deleting evolution from textbooks, Segye Ilbo maintained the angle of critical journalism. This showed that the newspapers' ownership and their owners' religious inclination did not always influence the perspectives of each published article.

The analysis of the formal frames of reports showed the episodic frame was dominant over the thematic frame accounting for over $60 \%$. The episodic frame focuses on the actualities of a story in accordance with the 5 W's and $1 \mathrm{H}$. In this case, speedy and sensational reporting is important. Though the thematic frame was attempted with quotations from the views of experts and journalists' columns, the media's overall coverage of the evolution controversy was largely subject to the episodic frame.

The analysis of the content frames indicated that the conflict news frame took up the largest portion with more than $30 \%$. The next biggest portion of the content frames was the responsibility frame $(28.6 \%)$, followed by the scientific interpretation frame $(16.7 \%)$ and the error of evolutionary theories frame (13.1\%). Notably, the scientific interpretation frame's ratio of $16.7 \%$ is higher than that of errors of evolutionary theories. As an evolutionary theory referred to in several science textbooksespecially the theory of linear evolution of horses - was quite outdated, many newspaper articles discussed the problems. Meanwhile, Kukmin Ilbo adhered to the frame of errors of evolutionary theories in order to attack evolution itself. Kukmin Ilbo was thus no different from STR, which demanded the removal of evolution in science textbooks. 


\section{Interviews of Journalists}

Why did you or did you not pay attention to the evolution controversy in Korea?

"I did not pay attention because I thought getting attention was exactly what STR wanted. When we decide that an issue is not worthy of a debate and of a news item, we just discard it from the range of choices. I thought this issue was not related to enhancing science and culture." - Journalist A

Most of the journalists I interviewed answered they had intentionally ruled out this issue. They had thought that STR's claims fell under the realm of religion, not into that of science. However, as it became imminent that evolutionary theory might be removed from textbooks quietly, Seoul Shinmun reported the news highlighting the issue. Although journalists thought that STR's purpose was to bring attention to the issue, this study found that STR's ultimate aim was removing evolutionary theory from textbooks. While most of the other newspapers decided that not bringing attention to the issue was a way of not playing into STR's intention, Seoul Shinmun reporters said that their swift reporting prevented the removal of evolutionary theory from textbooks.

What structural limits do you find in domestic science journalism regarding this issue?

"We did have a science reporter. I wanted to report the issue but could not afford to because I had to cover both science and the environment. I was quite frustrated about the situation. I believe most other newspapers except Dong-A (Donga Science) have similar problems. Science is difficult and boring. It's just that there are not many issues in science compared with politics, society and the economy. In other areas of society some new incidents happen every single hour. But that is not the case in science. That is why 
newspapers do not feel the need to assign a science journalist. Since science had limited space in the newspaper with a limited number of issues, we had limitations in getting into the debates on evolution." - Journalist B

Most of the media have few or no science journalists, amounting to one or two reporters at most, if any. Moreover, these reporters had to cover the environment, education or other fields adjacent to science, at the same time. Therefore, it was hard for media outlets to focus and follow up on one issue systematically unless it was a big headline story like the Hwang Woo Suk scandal and the Fukushima nuclear power plant accident. Clearly, full support is needed to foster science journalists so that the media might produce "worthwhile reports" on scientific issues.

How much influence do the NSC journals (Nature, Science and Cell) have on Korean science journalism?

"A lot. The NSC are not just journals. They work as communicators between scientists across different fields and journalists. Since the NSC journals carry trends of the scientific world, publication of an article in the NSC can be a good opportunity to bring attention to the issue. Being in the NSC is noteworthy as the overseas perspectives may be meaningful and especially as Korean scientists' papers rarely appear in the NSC journals. That is why an article published by one of these journals would often appear as a domestic newspaper's headline. These days this trend has somewhat decreased with the increase of Korean scholars' papers appearing in the NSC journals. Still, the NSC journals are a credible news source. The Hwang Woo Suk scandal became irreversible after the NSC journals carried an article about it. After Nature published an article on the textbook evolution controversy, evolutionary biologists finally began to react. As the situation moved on from phase 1 to phase 2 , the media began to shift from their strat- 
egy of ignoring STR's action. The issue began to be newly produced and journalists began to act." - Journalist A

The interviewees agreed that the NSC journals were an important news sources for most domestic newspapers except Kukmin Ilbo. The degree of the journals' influence on each newspaper differed depending on how much weight science carried in the newspaper and how interested the desk was in science. Also, the newspapers' interest in the NSC news sources and their utilization depended on whether scientific issues were handled by science journalists or not. This study found that domestic science journalism and journalists rely heavily on renowned overseas scientific journals, including the NSC.

Did you decide to take a stance on this issue before coverage, or afterwards?

"We had an editorial meeting where we clarified STR's position, the flaws in their logic and the circumstances of the Korean Society of Evolutionary Biology's failure to react in time. So, we already decided what our standpoint on the issue should be before covering it in print. But we did not reveal this standpoint to others outside of the company. Our company is in the mainstream of authentic science. So, we felt obliged to exclude other unreasonable claims or opinions. We were already familiar with the arguments of creation scientists and STR, so we did not feel the need to report them again. In other words, we already had our attitude toward this issue. We considered STR's position irrational and tried not to bring it to attention." - Journalist A

"Our company and I had no certain position on this issue. The perspective of the Korean Bible is based on creationism. I did not convey my judgement but rather STR's in my reports. They might have made mistakes. A journalist should be open to all questions and possibilities. We should not have prejudices before reporting. 
As a matter of fact, I wonder if evolutionary theory is scientifically correct. This theory came out 150 years ago. Then in the 1960s Stephen Jay Gould proposed a principle called NOMA (Nonoverlapping magisteria) ${ }^{7}$. It means scientific matters should belong to the domain of science and religious matters to that of religion. This idea is both right and wrong. After the NOMA principle, evolutionary theory began to be classified as science, while creationism and other similar arguments were considered non-scientific. Before that, there used to be no such division. As I studied these subjects I found neither of the two theories was complete yet. Both of them should be in ethics or philosophy textbooks but only evolution was included in science textbooks. In other words, evolution won, and evolutionists gained the upper hand. But evolution is only a theory. It is not a matter of science but of belief. Nothing is completely proven yet. Then why is it in science textbooks? It should be in ethics books. Should we accept the claim that protists became fish, fish became amphibians, amphibians became reptiles, reptiles became mammals and mammals became humans? Since this is what the textbooks taught us, we just believed it from childhood. But we must know that it could be a big hoax. Evolutionary theory has a lot of flaws because many unmatched puzzles were pieced together. There was no evolutionism up until 150 years ago. Unscientific matters should not be taught with textbooks. STR's aim is to get evolutionary theory out of textbooks. Why? Because it is wrong." - Journalist D

The interviewees answered their position depending on their inclina-

7 Stephen Jay Gould argued that science should have the magisterium over the actual world of nature while religion had magisterium over the moral territory of human lives and behaviors. His idea was that as the two domains did not overlap, there should be no need for conflict as long as each area stays on the right track. Source: Science Times, March 23, 2011 
tions and circumstances. Journalist A already had his position in accordance with the company's (Dong-A Ilbo/Donga Science) principles and the frame of authentic science before covering the issue. Journalist D also seemed to have approached the issue within the frame of Kukmin Ilbo's position and Christian beliefs.

Was the paper's conservative or progressive inclination relevant to this issue?

"In the case of the Hwang Woo Suk scandal, when it came to the question of whether to cover up any lie or flaw for the sake of protecting Doctor Hwang's position as the nation's leading scientist and national status, conservative papers might have argued, "The top priority is the nation. Small mistakes can be buried." Progressive ones might have said, "No way. He who will steal an egg will steal an ox," and abided by the principles of journalism. However, this issue has nothing to do with morality or national values. Ideology was irrelevant to the activities of Christian fundamentalism." - Journalist E

The conservative newspapers and the progressive ones that usually took opposite views on every single issue were on the same page this time. The interviewees said it was because the issue was not a grave matter with no room for ideological conflict. Some of the interviewees responded that while incidents like the Hwang Woo Suk scandal or the mad cow disease protest went beyond the realm of science, being open to ideological differences among newspapers, most scientific issues were not ideological. Other interviewees insisted that there could be ideological differences on whether science should be the realm for the elite or for the state and the public. This study demonstrated the possibility that science can transcend ideological differences and draw a unified voice from the media. Therefore, science journalists need to go beyond the boundary of their companies and make bipartisan efforts to find common ground through continuous exchanges and dialogue. 
Why did the two newspapers owned by religious foundations show different attitudes toward this issue?

"Our company's majority shareholder is a religious foundation. Most of the owners believe in creation rather than evolution. So, we rely on God's words and try to interpret science from creationistic viewpoints. There is much evidence of creation. It's a creationist's job to find the evidence of creation and the faults of evolution. How could men know things that happened three billion years ago? STR petitioned that the evolution theories about $\mathrm{Ar}$ chaeopteryx and horses were wrong and textbook publishers agreed with it. But evolutionists did not try to address the issue and instead accused creationists of attempting to dominate science. It was wrong for them to use the media in that way. A true scientist should acknowledge mistakes or try to come up with a reasonable counterargument. Evolutionists should not have driven the issue into a religious dispute." - Journalist D

"Our company is owned by a religious foundation, too. But Kukmin Ilbo has a section called "Mission Life," which demonstrates the owner's strong influence over the paper. In our case, we do not report the news of the Unification Church regularly unless there are special topics. The company's owner does not give us any directions, either. There seems to be some intervention and controlling in the system but not any direct interference. For instance, the foundation would appoint the editor-in-chief, but the media and the owner work separately in our company. While Kukmin Ilbo selects most of its journalists from among Christians, we choose journalists regardless of their religion, except only one or two from Sunmoon University graduates. Some of us even sometimes go against the Unification Church as we are conscious of the world's perceptions about us. Of course, the owner of our company rejects evolutionism officially as a member of a Chris- 
tian sect. But that is not the viewpoint of our newspaper. Our strong commitment to journalism also led us to take a different path to Kukmin Ilbo. All a reporter needs to care about is 'facts."' - Journalist E

Kukmin Ilbo and Segye Ilbo showed different attitudes toward this issue even though both of them are owned by religious foundations. It is because Kukmin Ilbo was influenced by its ownership and the inclinations of its shareholders while Segye Ilbo's owner only intervened in the company's system. Most of Kukmin's shareholders believed in creation rather than evolution and therefore the newspaper tried to understand science based on the Bible and its creationist perspectives. Segye's owner also opposed evolutionism officially as the newspaper was founded by the Unification Church, a Christian sect. But the interviewee from Segye Ilbo said the two newspapers showed different attitudes on this issue because of journalists' inclinations and Segye Ilbo reporters' professionalism. That is why, he said, Segye's owner and its articles go separate ways. This study concluded that the ownership and owners' inclinations did not have absolute influences on the direction of reports and that company owners and reports might take different paths depending on journalists' inclinations and their commitment to journalism.

Why did Kukmin llbo consistently use the frame of errors of evolutionary theory?

"Since God's creation is beyond our understanding, it is not easy to believe in it. There is no way to prove God's creation. That is why STR was organized. Now as STR studied evolutionary theory, they found it illogical. So, they pointed to errors of evolutionary theory and I wrote down their arguments. STR's ultimate goal is to get rid of evolutionary theory from textbooks at least. They had already prepared a list of evolutionary issues to be deleted. It is difficult for a journalist to judge which side of creationism and evolutionism is right. It is a scientist's job. Journalists should 
write facts. In other words, a reporter needs to cover the arguments of both sides. - Journalist D

Journalist D who had reported STR's position continuously explained that STR's aim was to remove evolutionary theory from textbooks. Because people would not have believed if STR had only talked about creationism, he said, STR tried to reveal loopholes in the evolutionary theory. He asserted that this was why his reports showed the evolution error frame frequently.

"I think Kukmin Ilbo is a newspaper for religious people, not for ordinary readers. They may well write about religious topics. But when it comes to textbook contents, which is in the public domain, it is a different story. They crossed the line on this issue. Would scientists criticize creation stories in a religious textbook? No. Nor would they make an issue of a birth myth of Korea in a Korean language textbook. The problem was that STR scientists drew a religious issue into science." - Journalist A

According to journalist $\mathrm{A}$, it does not matter whatever claims a religion may raise within the religious field, but religion should not interfere with textbooks, which belongs to the public domain.

Why did the controversy die down so fast given the significance of the issue? Is it possible for the controversy to resurface?

"I do not think the controversy will resurface. It seems things were wrapped up by the guidelines of the Korean Academy of Science and Technology and the official statement of the Minister of Education, Science and Technology. As long as the Korean Society of Evolutionary Biology makes proper adjustments to the textbook, there will be no problem." - Journalist A 
"There will be some changes, but the controversy will continue. Until now we did not have much debate on evolution compared with other societies. There are active discussions going on abroad, on intelligent design and so on. While evolutionists keep on developing their theory, creationists including STR also continue to research and build up their reasoning. So, no one knows if there will be some lawsuit arising over this matter in coming years. As an evolutionist I am worried this debate may turn into a waste of time and energy. Interestingly, scientists who have a religion are generally serious about creationism. They often say evolution is not enough to explain the birth of humankind's complicated life. As evolutionary theory is still in the making, this debate will go on.” - Journalist B

Some journalists said they intentionally closed this topic by drawing on the guidelines of the Korean Academy of Science and Technology and the official statement of the Minister of Education, Science and Technology as they were afraid that the situation might turn favorable toward STR if they dragged out the issue. They said the controversy would not reoccur if the Korean Society of Evolutionary Biology amends textbooks after thorough preparation. Yet one interviewee commented that creationists would continue their studies like evolutionists would. Therefore, unless some groundbreaking theory comes out, the reporter said, this kind of debate will go on.

Evolution and creation belong to different territories. The former is part of science, and the latter of religion. It will not be easy to narrow the gap between the two territories, if it is possible at all. We cannot predict whether this kind of dispute will resurface or not. Nevertheless, this study is intended to help scientists, religious people and journalists of the two territories understand their own turf better, strengthen their theories and respect each other so that there should be no more fruitless fighting. 


\section{Conclusion}

This paper has investigated South Korean journalists' approach to the evolution-creation debate incurred by STR's attempt to revise science textbooks in 2012. First, I have found, most Korean journalists began to pay serious attention to this debate only after it was reported in a premier overseas science journal, Nature, and then this problem was largely reported in the conflict frame. Second, a majority of journalists dealt with this issue factually, as revealed in their straight reporting style in the episodic frame. Third, this reporting relied more on individuals and organizations in science than those in religion. Fourth, the two newspapers owned by religious foundations addressed the debate differently, and Kookmin Ilbo was highly pro-creationist. I have thus shown that most South Korean journalists, except those in Kookmin Ilbo, did not view the debate as a serious cultural or political challenge that deserved significant and extensive media coverage. To many, the debate was just a matter of dry scientific facts that would barely attract readers' attention, unless it was reported in a major overseas journal.

I think that the debate is a manifestation of the persistent controversy that is still going on in Korea. I expect that the controversy cannot be easily resolved, as it is relevant to two separate domains, science and religion. Indeed, evolution and creation belong to different territories. The former is a part of science, and the latter a portion of religion. It will not be easy to narrow the gap between the two territories, if it is possible at all. We cannot predict whether this kind of dispute will resurface or not. Nevertheless, this study is intended to help scientists, religious people and journalists of the two areas to understand their own turf better, strengthen their theories and respect each other so that there should be no more fruitless fighting.

Of course, my research has some limitations. First, the eight newspapers produced a mere 84 articles on this issue, which is very low coverage given the importance of the subject. This extent of coverage was enough to interpret the reporting attitudes, but not enough to fully understand the 
depth of the subject. Second, I had to exclude broadcast reports because their coverage was much lower and simpler than that of newspapers. Although I wanted to include all types of media, adding broadcast coverage would have compromised the quality of the study. Third, I wish I could have investigated the data of social media as well. Social media has become as influential as conventional media, including newspapers, magazines and broadcasting. The textbook evolution controversy had already been debated in online bulletin boards of the domestic media and of BRIC (Biological Research Information Center), as well as in overseas news websites. But it was difficult to clarify and analyze unrefined words and vague opinions of short unclear messages on social media. If I had succeeded in analyzing the discussions of social media, this research would had broader scope.

\section{References}

1. Breed, Warren. "Social Control in the Newsroom: A Functional Analysis." Social Forces 33, Issue 4 (May 1955): 326-35. https://doi.org/10.2307/2573002.

2. Christi, Frances and J. R. Martin. Genre and Institutions: Social Processes in the Workplace and School. London: Continuum, 1997.

3. Entmann, Robert M. "Framing U. S. Coverage or International News: Contrast in Narratives of the KAL and Iran Air Incident." Journal of Communication 41, Issue 4 (December 1991): 6-27. https://doi.org/10.1111/j.1460-2466.1991.tb02328.x.

4. Entmann, Robert M. "Framing U. S. Coverage or International News: Contrast in Narratives of the KAL and Iran Air Incident." Journal of Communication 41, Issue 4 (December 1991): 6-27. https://doi.org/10.1111/j.1460-2466.1991.tb02328.x.

5. Gang, Seokgi. "Humans and Horses, The Most Beautiful Evolution." Kwahaktonga (Donga Science) 320 (August 2012): 144-5.

6. Gang, Seokgi et al. Ch'ŏngsonyŏni Kkok Araya Hal Kwahagisyu 11 
(11 Scientific Issues for Young Adults). Seoul: Donga M\&B, 2015.

7. Gans, Herbert J. Deciding What's News. New York: Vintage Books, 1979.

8. Gitlin, Todd. The Whole World is Watching: Mass Media in the Making and Unmaking of the New Left. Berkeley: University of California Press, 1980.

9. Iyengar, Shanto. Is Anyone Responsible?: How Television Frame Political Issues. Chicago: University of Chicago Press, 1991.

10. KAIST Science Journalism Research Team. "Analysis of Media Coverage on Samgsung-Apple Patent Lawsuit." The $2^{\text {nd }}$ KAIST Science Journalism Review Conference 2012, Seoul, Republic of Korea, 2012.

11. Kurpius, David D. "Sources and Civic Journalism: Changing Patterns of Reporting?" Journalism \& Mass Communication Quarterly 79, Issue 4 (Winter 2002): 853-66. https://doi.org/10.1177/10776990 0207900406.

12. Lee, Chunghwan. "Kwahak Podo Silp'aee Taehan ANT Sarye Punsǒk (Analysis of ANT Cases of Failed Science Reports)." PhD diss., Korea University, 2013.

13. Pan, Zhongdang and Gerald M. Kosicki. "Framing Analysis: An Approach to News Discourse." Political Communication 10, Issue 1 (2010): 55-75.

14. Park, Jongin. Saiŏnsŭ Chŏnŏllijŭm (Science Journalism). Seoul: Communications Books, 2012.

15. Semetko, Holli A. and Patti M. Valkenburg. "Framing European Politics: A Contest Analysis of Press and Television News." Journal of Communication 50, Issue 2 (June 2000): 93-109. https://doi.org/10. 1111/j.1460-2466.2000.tb02843.x.

16. Shoemaker, Pamela J. and Stephen D. Reese. Mediating the Message: Theories of Influences on Mass Media Content. New York: Longman, 1996.

17. Sumpter, Randall S. and Melissa A. Braddock. "Source Use in a 'News Disaster' Account: A Content Analysis of Voter News Ser- 
vice Stories." Journalism \& Mass Communication Quarterly 79, Issue 3 (September 2002): 539-58. https://doi.org/10.1177/107769900 207900302.

18. White, David M. "The 'Gatekeeper': A Case in the Selection of News.” Journalism Quarterly 27, issue 4 (September 1950): 383-90.

19. Wimmer, Roger D. and Joseph R. Dominick. Mass Media Research; An Introduction. New York: Thomson Wadsworth, 2006. 


\section{A Study of News Frames on the Controversy over Evolu- tionary Theories in South Korean Science Textbooks}

This study investigates how Korean media dealt with a dispute between evolutionists and creationists over how to handle Archaeopteryx in science textbooks. This study found most journalists did not intentionally highlight the issue while the Seoul Shinmun aroused readers' attention to it with swift reports. This study was designed to examine why some media firms intentionally avoided the issue, what differences conservative and progressive news media showed, and how newspapers owned by churches responded to the controversy. I analyzed all reports from eight media outlets and conducted in-depth interviews with five journalists who covered the issue.

This study found Korea's science journalism, in general, is in poor condition despite its increasingly important role. It is difficult for media companies to have a professional science journalist. Moreover, they cannot concentrate on science issues because of other overlapping responsibilities. It is high time for the Korean media industry to address this problem in order to generate higher-quality science stories.

Korean science journalists are also highly dependent on renowned foreign journals including NSC, one of the crucial sources of information and scientific news. They should consider how to reduce such reliance.

The dispute between evolutionists and creationists will not be resolved any time soon. Neither has been fully proved. One is in the realm of science and the other is in the realm of religion. It will be difficult to narrow their differences. This study hopefully highlights the need for journalists, scientists and religious circles to better understand the essences of their own area, develop their theoretical foundation, and respect the others' fields. 
Keywords: Archaeopteryx, horse, science textbook, dispute between evolutionists and creationists 


\section{〈국문초록〉}

\section{한국 과학교과서의 진화론 논쟁과 그에 대한 뉴스 프레임 연구}

대한민국 최초의 진화론 논쟁이 일어났다. 그러나 대부분의 기자들은 의도적으 로 이것을 이슈화하지 않았음이 연구 결과 드러났다. 사안의 중요성에도 불구하고 왜 어떤 언론사는 이슈화했고, 어떤 언론사는 의도적으로 배제했는지 연구할 가치 를 느꼈다. 또 굵직한 과학이슈가 터질 때마다 서로 다른 입장을 취했던 보수지와 진보지는 이번 이슈에 대해서는 어떤 편향성을 취했는지 궁금했다. 또 종교재단이 주주로 되어 있는 매체는 어떤 보도태도와 편향성을 보였는지도 궁금했다.

언론사 8 곳의 기사를 총 망라해 내용분석을 했다. 그러나 원하는 결과를 얻을 수 없었다. 그래서 당시 이 이슈를 담당했던 5 명의 담당기자를 심층인터뷰 해 추 가조사를 하였다.

점점 과학전문 기자의 역할은 커져가고 있었지만 현재 국내 과학저널리즘의 상 황은 열악했다. 한 언론사에서 과학전문 기자를 갖추기도 어렵고, 갖췄다고 해도 여러 영역을 중복해서 맡느라 과학 분야의 심층 취재하는데 구조적 어려움이 드 러났다. 과학 분야의 질 높은 기사를 생산하기 위해서는 이런 구조적인 한계를 극 복할 방안을 고민해야 할 때다.

또한 국내 과학기자의 NSC(Nature紙, Science紙, Cell紙)를 비롯한 외국의 저명 과학저널에 대한 의존도도 높았다. NSC는 중요한 취재원의 하나로서 거기에 실리 는 연구는 이슈화할 수 있는 기폭제가 된다고 했다. 그러나 더불어 $\mathrm{NSC}$ 의 권위 에 의존하는 국내 과학저널리즘의 반성과 그것을 극복할 수 있는 대안 또한 요구 된다고 하겠다.

이번 연구 결과 진화론과 창조론 논쟁은 쉽게 해결되지 않을 것으로 보인다. 진 화론과 창조론은 완벽하게 증명되지도 완성되지도 않은 학문이다. 또 한쪽은 과학 의 영역에 있고 다른 한쪽은 종교의 영역에 있다. 두 영역 간의 간격은 쉽게 좁혀 들지 않을 것이다. 아니면 영원히 좁혀지지 않을 지도 모른다. 그래서 이 같은 논 쟁이 재발할지 아닐지는 아무도 장담할 수 없다. 그러나 이번 사건을 계기로 두 
영역에 있는 과학자나 종교인, 그리고 기자들이 자신의 영역에 대한 본질을 더욱 이해하고, 이론을 더욱 공고히 하고, 서로의 영역을 존중해주는 계기가 되었으면 하는 것이 본 연구가 지향하는 바이다.

주제어: 시조새, 말, 과학교과서, 진화론 논쟁 
